\title{
Abnormal Glutamate Receptor Expression in the Medial Temporal Lobe in Schizophrenia and Mood Disorders
}

\author{
Monica Beneyto*,', Lars V Kristiansen ${ }^{2}$, Akinwunmi Oni-Orisan ${ }^{2}$, Robert E McCullumsmith ${ }^{2}$ and \\ James H Meador-Woodruff ${ }^{2}$ \\ 'Department of Psychiatry, University of Pittsburgh, Pittsburgh, PA, USA; ${ }^{2}$ Department of Psychiatry and Behavioral Neurobiology, University of \\ Alabama at Birmingham, Birmingham, AL, USA
}

\begin{abstract}
Pharmacological and anatomical evidence suggests that abnormal glutamate neurotransmission may be associated with the pathophysiology of schizophrenia and mood disorders. Medial temporal lobe structural alterations have been implicated in schizophrenia and to a lesser extent in mood disorders. To comprehensively examine the ionotropic glutamate receptors in these illnesses, we used in situ hybridization to determine transcript expression of N-methyl-D-aspartate (NMDA), $\alpha$-amino-3-hydroxy-5-methyl-4-isoxazole propionate (AMPA), and kainate receptor subunits in the medial temporal lobe of subjects with schizophrenia, bipolar disorder (BD), or major depression (MDD). We used receptor autoradiography to assess changes in glutamate receptor binding in the same subjects. Our results indicate that there are region- and disorder-specific abnormalities in the expression of ionotropic glutamate receptor subunits in schizophrenia and mood disorders. We did not find any changes in transcript expression in the hippocampus. In the entorhinal cortex, most changes in glutamate receptor expression were associated with BD, with decreased GluR2, GluR3, and GluR6 mRNA expression. In the perirhinal cortex we detected decreased expression of GluR5 in all three diagnoses, of GluRI, GluR3, NR2B in both BD and MDD, and decreased NRI and NR2A in BD and MDD, respectively. Receptor binding showed NMDA receptor subsites particularly affected in the hippocampus, where MK80I binding was reduced in schizophrenia and BD, and MDLI05,5I9 and CGP39653 binding were increased in BD and MDD, respectively. In the hippocampus AMPA and kainate binding were not changed. We found no changes in the entorhinal and perirhinal cortices. These data suggest that glutamate receptor expression is altered in the medial temporal lobe in schizophrenia and the mood disorders. We propose that disturbances in glutamate-mediated synaptic transmission in the medial temporal lobe are important factors in the pathophysiology of these severe psychiatric illnesses.

Neuropsychopharmacology (2007) 32, I888-1902; doi: I0.1038/sj.npp. I 30 I3 I2; published online I4 February 2007
\end{abstract}

Keywords: hippocampus; perirhinal cortex; entorhinal cortex; depression; bipolar disorder; ionotropic receptors

\section{INTRODUCTION}

The hypothesis that glutamate is involved in the pathogenesis of severe mental illness was initially based in part on the effects of the hallucinogenic drug phencyclidine (PCP). $\mathrm{PCP}$, and similar compounds that antagonize the $\mathrm{N}$-methylD-aspartate (NMDA) receptor, can induce a schizophreniform psychosis in normal individuals and exacerbate these symptoms in schizophrenia (Hertzmann et al, 1990). Interestingly, other pharmacological studies and theoretical considerations have also implicated $\alpha$-amino-3-hydroxy-5methyl-4-isoxazole propionate (AMPA) receptor dysfunction in schizophrenia. Positive modulators of the AMPA

*Correspondence: Dr M Beneyto, Department of Psychiatry, University of Pittsburgh, WI 656 Biomedical Science Tower, 38I I O'Hara Street, Pittsburgh, PA 15213, USA, Tel: + 412383 54|5, Fax: + 412 62499 I0, E-mail: beneytom@upmc.edu

Received 7 June 2006; revised 13 November 2006; accepted 14 November 2006 receptor, called ampakines, improve cognitive function in schizophrenia, whereas enhancement of AMPA receptormediated currents by these compounds may potentiate the activity of antipsychotic medications (Coyle, 1996). In vitro studies have demonstrated that NMDA and AMPA receptors colocalize in the postsynaptic membrane, acting synergistically at glutamatergic synapses (Kharazia et al, 1996).

The ionotropic AMPA, kainate, and NMDA glutamate receptors mediate most of the fast excitatory neurotransmission in the brain. AMPA receptors are ligand-gated channels that mediate the majority of low-frequency neurotransmission at glutamatergic synapses, and are heteromeric assemblies of GluR1-4 subunits. Kainate receptors are also ligand-gated ion channels composed of tetrameric combinations of five subunits, GluR5-7, KA1, and 2. Kainate receptors are located both post- and presynaptically, and influence the activity of other postsynaptic glutamate receptors by facilitating glutamate release and by modulating $\gamma$-aminobutyric acid (GABA)- 
ergic activity (Jiang et al, 2001). Variations in subunit composition or number of kainate receptors may therefore alter presynaptic glutamate release and/or the firing rate of NMDA and AMPA receptors.

NMDA receptors are tetrameric combinations of seven subunits, NR1, NR2A-D, NR3A, and 3B, with multiple binding sites including ones for glutamate, polyamine, $\mathrm{Mg}^{+2}$, and glycine. The pharmacological regulation of the NMDA receptor depends on unique combinations of subunit-specific binding sites. The glycine (D-serine) coagonist site must be occupied before glutamate activates the ion channel. Neurotransmission mediated by ionotropic glutamate receptors underlies several forms of synaptic plasticity in the hippocampus, including long-term potentiation (LTP) and depression (LTD) (Bliss and Collingridge, 1993; Isaac et al, 1995; Linden and Connor, 1995; Nicoll and Malenka, 1995; Selig et al, 1995; Bear and Abraham, 1996; Wu et al, 1996; Bear and Rittenhouse, 1999; Malenka and Nicoll, 1999). AMPA receptor colocalization with the NMDA receptor is required for LTP and other molecular correlates of learning, memory, and cognitive functions, highlighting the importance of ionotropic glutamate receptor function in the medial temporal lobe (Siegel et al, 1995).

The medial temporal lobe includes a system of anatomically related structures that are essential for establishing long-term declarative memory, likely due to their widespread and reciprocal connections with the neocortex. This system consists of the hippocampal region (CA subfields, dentate gyrus (DG), and subicular complex) and adjacent, anatomically related cortex, including entorhinal, perirhinal, and parahippocampal cortices. The entorhinal cortex, located in the ventromedial portion of the temporal lobe, has reciprocal connections with the hippocampus and other cortical and subcortical structures. The perirhinal cortex is a polymodal association area that contributes to recognition memory. Recent findings from lesion and electrophysiological studies suggest that this area participates in a broad range of memory functions, including both associative memory and emotional, as well as in consolidation functions. These results are consistent with neuroanatomical research showing that this area has strong reciprocal connections with widespread cortical sensory areas and with other memory-related structures, including the hippocampal formation and amygdala (Stefanacci et al, 1996; Suzuki, 1996; Wan et al, 1999).

Converging lines of evidence have implicated the medial temporal lobe in severe mental illness. Imaging approaches including magnetic resonance imaging (MRI) (Bogerts et al, 1990a,b; Lawrie and Abukmeil, 1998; Nelson et al, 1998; Lawrie et al, 1999; Velakoulis et al, 1999; Wright et al, 2000; Csernansky et al, 2002; Joyal et al, 2002; Pantelis et al, 2003), proton MRI (Maier et al, 1995; Bertolino et al, 1996, 1998; Deicken et al, 1999), and positron emission tomography (Friston et al, 1992; Tamminga et al, 1992; Medoff et al, 2001) have found abnormalities including decreased gray matter volumes in the medial temporal lobe in schizophrenia and bipolar disorder (BD). Neuropathology measures constitute the most substantial body of data for hippocampal involvement in serious mental illness, finding changes in neuronal size, density, and localization in the hippocampus in schizophrenia and BD, and to a lesser extent in major depressive disorder (MDD) (Arnold, 1997;
Benes et al, 1998, 1999; Harrison, 1999; Weinberger, 1999; Harrison and Eastwood, 2001; Heckers and Konradi, 2002; Rajkowska, 2002a,b). Neurochemical studies suggest alterations in ionotropic glutamate receptor expression in schizophrenia, although contradictory data have been published (Gao et al, 2000; Law and Deakin, 2001). Taken together, these findings, and the role of glutamate as the major excitatory neurotransmitter in medial temporal structures, suggest that medial temporal lobe glutamatergic neurotransmission is compromised in schizophrenia and the mood disorders. We hypothesize that the expression of glutamate receptor subunits and/or binding of ionotropic glutamate receptors is altered in the medial temporal lobe in schizophrenia and the mood disorders, possibly reflecting an abnormal stoichiometry of the receptor.

\section{MATERIALS AND METHODS}

\section{Subjects and Tissue Preparation}

This study was performed using postmortem brains from 60 subjects obtained from the Stanley Foundation Neuropathology Consortium, consisting of four groups of 15 subjects, with diagnoses of schizophrenia, BD, MDD, and a comparison group (Torrey et al, 2000) (Table 1). These groups are matched for age, sex, race, postmortem interval (PMI), mRNA quality, brain $\mathrm{pH}$, and hemisphere studied. Serial sections $(14 \mu \mathrm{m})$ were provided by the Stanley Foundation and stored at $-80^{\circ} \mathrm{C}$.

\section{In Situ Hybridization Histochemistry}

Riboprobes were synthesized from linearized plasmids containing subclones of each of the ionotropic glutamate receptor subunits. Each probe recognizes all known isoforms and editing variants of each subunit (Table 2). In brief, $5 \mu \mathrm{l}$ of $\left[{ }^{35} \mathrm{~S}\right]$-UTP were dried and $2.0 \mu \mathrm{l} 5 \mathrm{X}$ transcription buffer, $1.0 \mu \mathrm{l} 0.1 \mathrm{M}$ dithiothreitol (DTT), $1.0 \mu \mathrm{l}$ each of $10 \mathrm{mM}$ ATP, CTP, and GTP, $2.0 \mu \mathrm{l}$ linearized plasmid, $0.5 \mu \mathrm{l}$ RNase inhibitor, and $1.5 \mu \mathrm{l}$ T7 or Sp6 RNA polymerase were mixed and incubated for $2 \mathrm{~h}$ at $37^{\circ} \mathrm{C}$. $1.0 \mu \mathrm{l}$ DNase (RNase-free) was then added, and the mixture was incubated for $15 \mathrm{~min}$ at room temperature. The reaction mixture was loaded on spin columns (Micro Bio-Spin P-30 Tris Chromatography Columns, Bio-Rad Laboratories, Richmond, CA) and the purified fraction was eluted. DTT was added to each fraction to a final concentration of $0.01 \mathrm{M}$.

Two slides per subject for each probe were removed from $-80^{\circ} \mathrm{C}$ storage and placed in $4 \%$ (weight:vol) formaldehyde at room temperature for $1 \mathrm{~h}$. They were then rinsed in $2 \times$ SSC (standard saline citrate, $300 \mathrm{mM}$ sodium chloride, and $30 \mathrm{mM}$ sodium citrate, $\mathrm{pH}$ 7.2) and subsequently treated with $0.1 \mathrm{M}$ triethanolamine ( $\mathrm{pH} 8.0$ )/acetic anhydride (400:1) with stirring for $10 \mathrm{~min}$ at room temperature. The sections were rinsed in $2 \times$ SSC for $5 \mathrm{~min}$ and dehydrated in graded alcohols before air drying. $\left[{ }^{35} \mathrm{~S}\right]$-labeled probes were applied diluting $3-5 \times 10^{6}$ c.p.m. in $400 \mu \mathrm{l}$ per slide in hybridization buffer ( $50 \%$ deionized formamide, $3 \times$ SSC, $1 \times$ Denhardt's solution $(0.02 \%$ polivinyl pyrrolidone, $0.02 \%$ Ficoll, $0.02 \%$ bovine serum albumin), $2 \%$ yeast tRNA $(10 \mathrm{mg} / \mathrm{ml}), 50 \mathrm{mM}$ sodium phosphate $(\mathrm{pH} 7.4)$, and $10 \%$ 
Table I Characterization of Subjects

\begin{tabular}{|c|c|c|c|c|}
\hline & Schizophrenia & Major depression & Bipolar disorder & Normal controls \\
\hline$n$ & 15 & 15 & 15 & 15 \\
\hline Age (years) & $44.2(25-62)$ & $46.4(30-65)$ & $42.3(25-61)$ & $48.1(29-68)$ \\
\hline Sex (male/female) & $9 / 6$ & $9 / 6$ & $9 / 6$ & $9 / 6$ \\
\hline Race & $13 \mathrm{C}, 2 \mathrm{~A}$ & $15 \mathrm{C}$ & I4C, IAA & I4C, IAA \\
\hline PMI (hours) & $33.7(|2-6|)$ & $27.5(7-47)$ & $32.5(13-62)$ & $23.7(8-42)$ \\
\hline Side of brain & 6 right, 9 left & 6 right, 9 left & 8 right, 7 left & 7 right, 8 left \\
\hline Suicide & $4 / 15$ & $7 / 15$ & $9 / 15$ & $0 / 15$ \\
\hline $\mathrm{EtOH}$ use $^{\mathrm{a}}$ & $5 / 15$ & $3 / 15$ & $5 / 15$ & $1 / 15$ \\
\hline Medication ${ }^{\mathrm{b}}$ & $12 / 15$ & $14 / 15$ & $12 / 15$ & $0 / 15$ \\
\hline SSRI & $2 / 15$ & $4 / 15$ & $2 / 15$ & $0 / 15$ \\
\hline
\end{tabular}

C, Caucasian; AA, African American; A, Asian; EtOH, ethanol; SSRI, selective serotonin reuptake inhibitor.

a History of active $\mathrm{EtOH}$ abuse or dependence at time of death.

${ }^{b}$ Treatment with psychotropic medication within 6 weeks of time of death.

'Other mood stabilizers: carbamazepine and valproic acid.

dextran sulfate in sterile water). Slides were covered with glass cover slips, and placed in humidified chambers containing blotter paper saturated with $50 \%$ formamide at $55^{\circ} \mathrm{C}$ overnight.

After $16 \mathrm{~h}$ of hybridization, cover slips were removed and sections were washed three times in $2 \times$ SSC at room temperature, immersed in RNAse A $(200 \mathrm{mg} / \mathrm{ml}$ in $10 \mathrm{mM}$ Tris, $0.5 \mathrm{M} \mathrm{NaCl}, \mathrm{pH} 8.0$ ) for $30 \mathrm{~min}$ at $37^{\circ} \mathrm{C}$, and then washed through decreasing concentrations of SSC to a final stringency of $0.5 \times \mathrm{SSC}$ at $55^{\circ} \mathrm{C}$ for $1 \mathrm{~h}$. Finally, the sections were dehydrated in increasing concentrations of ethanol, air dried, placed in X-ray cassettes, and apposed to Kodak Biomax MR film (Kodak, Rochester, NY) for 7-10 days. For each probe, all subjects were run in the same experiment to eliminate interassay variability. Control slides were used to confirm the specificity of each riboprobe, running 'sensestrand' labeled sections in parallel with those labeled with 'antisense-strand' probes.

\section{Receptor Autoradiography}

The conditions to determine binding to NMDA, AMPA, and kainate receptors have been previously described in detail (Healy et al, 1998; Healy and Meador-Woodruff, 1999; Ibrahim et al, 2000a,b), and used established receptor autoradiography assays methods (Huettner and Bean, 1988; Ransom and Stec, 1988; Sills et al, 1991; Hashimoto et al, 1994; Baron et al, 1996; Siegel et al, 1996; White and Vogel, 1996). We examined multiple binding sites on the NMDA receptor, including the intrachannel site (visualized with $\left.\left[{ }^{3} \mathrm{H}\right] \mathrm{MK}-801\right)$, polyamine site $\left(\left[{ }^{3} \mathrm{H}\right]\right.$ ifenprodil), glutamate site $\left(\left[{ }^{3} \mathrm{H}\right] \mathrm{CGP} 39653\right)$, and glycine (D-serine) coagonist site $\left(\left[{ }^{3} \mathrm{H}\right]\right.$ MDL105,519). $\left[{ }^{3} \mathrm{H}\right] \mathrm{AMPA}$ and $\left[{ }^{3} \mathrm{H}\right]$ kainate were used to label those respective receptors. Slides from these studies were apposed to Amersham (Piscataway, NJ) $\left[{ }^{3} \mathrm{H}\right]$ Hyperfilm for 2 days $\left(\left[{ }^{3} \mathrm{H}\right]\right.$ MDL105,519), 3 days $\left(\left[{ }^{3} \mathrm{H}\right]\right.$ ifenprodil $), 1$ week $\left(\left[{ }^{3} \mathrm{H}\right]\right.$ MK-801), 2 weeks $\left(\left[{ }^{3} \mathrm{H}\right] \mathrm{CGP} 39653\right)$, or 3 weeks $\left(\left[{ }^{3} \mathrm{H}\right] \mathrm{AMPA}\right.$ and $\left[{ }^{3} \mathrm{H}\right]$ kainate). Hyperfilm was developed in Kodak D-19 $\left(4 \mathrm{~min}\right.$ at $\left.19^{\circ} \mathrm{C}\right)$, agitated in $2 \%$ acetic acid $(30 \mathrm{~s})$, fixed in Kodak Rapidfix ( $5 \mathrm{~min})$, washed under running water (10 min) and air dried. Nonspecific binding was determined in adjacent slides from each subject by adding a specific blocker for each binding site $\left(\left[{ }^{3} \mathrm{H}\right] \mathrm{MK}\right.$ 801: unlabeled MK-801; $\left[{ }^{3} \mathrm{H}\right]$ ifenprodil: spermine; $\left[{ }^{3} \mathrm{H}\right]$ CGP39653: glutamate; $\left[{ }^{3} \mathrm{H}\right] \mathrm{MDL} 105,519:$ glycine; $\left[{ }^{3} \mathrm{H}\right] \mathrm{AMPA}$ and $\left[{ }^{3} \mathrm{H}\right]$ kainate: CNQX) (Ibrahim et al, 2000a).

\section{Image Analysis}

Image analysis of in situ hybridization films. Developed films were digitized and quantitated using NIH image (v1.56) on a CCD-based imaging system. In the hippocampus, measurements were taken from the CA1, CA2, CA3, and CA4 subfields, DG, and subiculum (Sub). In the entorhinal and perirhinal cortices, each subunit had a distinct laminar distribution across the cortical thickness, and gray-scale values were obtained from discrete bands with density different from adjacent lamina (isodense bands). By overlapping images from Nissl counterstaining of the same slides we were able to correlate isodense bands to traditional cytoarchitectural layers. Gray scale values from hippocampal regions and cortical isodense bands were corrected for tissue background, and converted to optical density (OD). The amount of radioactivity bound (in $\mathrm{nCi} / \mathrm{g}$ ) was determined using $\left[{ }^{14} \mathrm{C}\right]$ microscale standards (Amersham Biosciences, Piscataway, NJ) (Miller, 1991), which were exposed on the same film as the slides for each study. Using the number of uridine nucleotides contained in each probe, the bound radioactivity value was converted to concentration of mRNA per hippocampal region or cortical isodense band, expressed as fmol/g of tissue. The values from two slides per subject were averaged to obtain a single value for each mRNA for each hippocampal region or cortical isodense band. 
Table 2 lonotropic Subunit Transcript Changes in Medial Temporal Lobe Structures

Tukey HSD post-hoc test

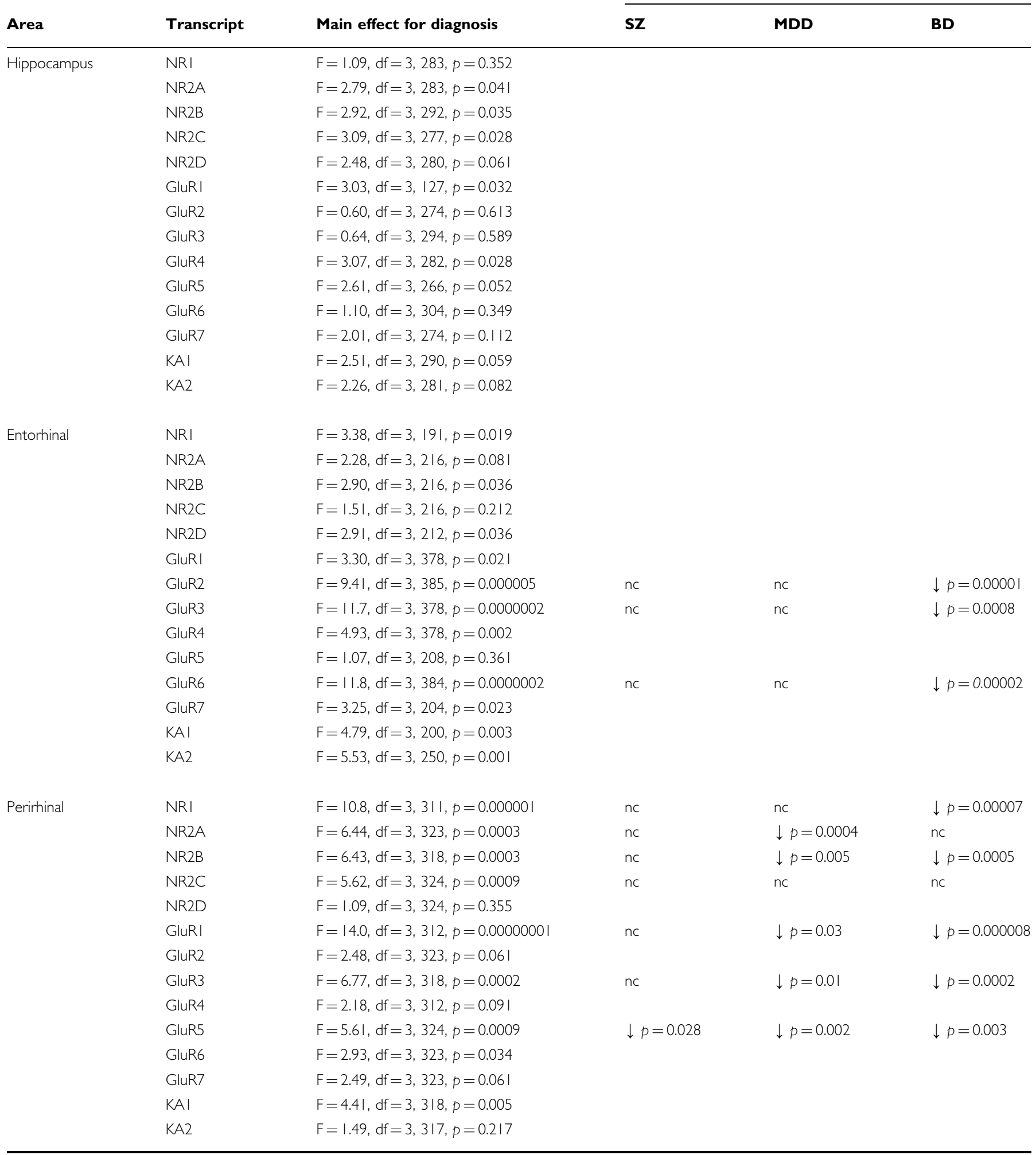

Image analysis of receptor autoradiography. Developed films were digitized and quantitated using the NIH imaging software program. For each hippocampal region and cortical isodense band, gray scale values from the 'total' binding were corrected for nonspecific binding from an adjacent slide for each subject, and absolute gray values were converted to OD. The amount of radioactivity bound (in $\mathrm{nCi} / \mathrm{g}$ ) was determined using $\left[{ }^{14} \mathrm{C}\right]$ microscale standards 
(Amersham Biosciences) (Miller, 1991), which were exposed on the same film as the slides for each study. From specific activity of each ligand, and percentage of receptor occupancy for the ligand (approximately $78 \%$ at three times $K_{\mathrm{d}}$ ), values of bound radioactivity were converted to concentration of receptor binding per hippocampal region or cortical isodense band, expressed as $\mathrm{pmol} / \mathrm{g}$ of tissue. The final value was averaged from two slides per subject.

\section{Statistical Analysis}

The dependent variable in the in situ hybridization studies was the mRNA concentration for each receptor subunit in each hippocampal region or cortical isodense band, whereas for receptor autoradiography the dependent variable was the concentration of receptor binding. For each dependent variable, correlation analysis was performed to test for associations between PMI, age, $\mathrm{pH}$, and each dependent variable. If correlations were found $(\alpha=0.05)$ we used analysis of covariance (ANCOVA) to test the effect of diagnosis on mRNA or binding sites. When no significant correlations were detected, the effect of diagnosis on mRNA concentration and binding sites was determined by factorial analysis of variance (ANOVA), with diagnosis and isodense band or hippocampal subfield treated as independent variables for each area. We applied Bonferroni correction by which $\alpha=0.001$. Post hoc analyses were performed using Tukey's honesty significant difference test and $\alpha=0.05$ was used for significance (Tables 2 and 3, Supplementary Tables S4 and S5).

\section{RESULTS}

\section{In Situ Hybridization}

All glutamate ionotropic receptor subunit transcripts were detected in the medial temporal lobe structures examined. Sense strand riboprobes did not produce any specific labeling (data not shown).

\section{Hippocampal Formation}

NMDA subunit mRNAs. NMDA subunit mRNA expression was highest for NR1, followed by NR2B and NR2A; NR2C and NR2D were considerably lower in the hippocampus. All NMDA subunits were expressed in a similar distribution in hippocampal structures (Figure 1a-e). In the hippocampal formation, we found an association between NR1 mRNA expression and $\mathrm{pH}(r=0.55, p<0.01)$. We also found an association between $\mathrm{pH}$ and NR2A $(r=0.53, p<0.0001)$ and NR2B $(r=0.47, p<0.001)$. Using ANCOVA with $\mathrm{pH}$ as a covariate for NR1, NR2A, and NRB, we did not detect a main effect for diagnosis for these subunits. No association between NR2C and NR2D and pH, PMI, or age was found, and ANOVA did not detect a main effect of diagnosis the expression of these subunits (Table 2, Supplementary Figure S6).

AMPA subunit mRNAs. Similar to the NMDA receptor subunits, AMPA subunits were expressed in all hippocampal subregions (Figure $2 \mathrm{a}-\mathrm{d}$ ). We found an association between $\mathrm{pH}$ and GluR1 $(r=0.38, p=0.003)$, GluR2 $(r=0.43, p<0.0005)$, and GluR3 expression $(r=0.43$, $p=0.0005)$. ANCOVA showed no main effect for diagnosis for any of these AMPA subunits. Using ANOVA, we also found no change of GluR4 expression (Table 2, Supplementary Figure S7).

Kainate subunit mRNAs. Kainate subunit transcripts were expressed in all hippocampal regions (Figure $3 \mathrm{a}-\mathrm{d}$ ). We found an association between GluR5 and $\mathrm{pH}(r=0.35$, $p=0.006)$, between GluR7 and PMI $(r=0.26, p=0.04)$ and $\mathrm{pH}(r=0.47, p=0.0002)$, and between $\mathrm{pH}$ and both KA1 $(r=0.43, p=0.0008)$ and KA2 $(r=0.45, p=0.0004)$. ANCOVA using $\mathrm{pH}$ as a covariate for GluR5, KA1 and KA2, and PMI for GluR7, showed no significant changes in expression of these molecules. Likewise, ANOVA for GluR6 did not detect any effect of diagnosis (Table 2, Supplementary Figure S8).

\section{Entorhinal Cortex}

NMDA subunit mRNAs. All NMDA subunits showed four isodense bands of relatively higher intensity corresponding to cortical layers II, III, IV and V, and VI (Figure 1a-e). Regression analysis showed an association between NR1 and $\mathrm{pH} \quad(r=0.33, p=0.018)$. ANCOVA using $\mathrm{pH}$ as covariate showed no main effect of diagnosis for NR1. Using ANOVA, we did not detect a main effect for diagnosis for any other NMDA subunits (Table 2, Supplementary Figure S9).

AMPA subunit mRNAs. In the entorhinal cortex, all AMPA receptor subunits were expressed in seven isodense bands (Figure $2 \mathrm{a}-\mathrm{d}$ ). There were no associations between PMI, $\mathrm{pH}$, or age with any AMPA subunit transcript. Although no change was found for the expression of GluR1 and GluR4 subunits, ANOVA revealed a main effect for diagnosis for GluR2 $(\mathrm{F}=9.4, \mathrm{df}=3,385, p<0.0001)$ and GluR3 $(\mathrm{F}=11.7$, $\mathrm{df}=3,378, p<0.0001)$, with no diagnosis by layer interactions. Post hoc tests showed decreased GluR2 $(p<0.0001)$ and GluR3 expression $(p<0.001)$ in BD compared to controls (Table 2, Supplementary Figure S10).

Kainate subunit mRNAs. All kainate subunits were expressed in the entorhinal cortex, but with different distribution patterns. GluR5 had very low expression levels, followed by GluR6, KA1 and KA2 with moderate hybridization signal, and GluR7 with the strongest expression level in this cortical area (Figure $3 \mathrm{a}-\mathrm{e})$. We found an association between GluR6 expression and $\mathrm{pH}(r=0.3, p=0.02)$. ANCOVA revealed a main effect for diagnosis for GluR6 $(\mathrm{F}=11.82, \mathrm{df}=3,384, p<0.0001)$, with no diagnosis by isodense band interaction. Post hoc analysis showed decreased expression of this subunit $(p<0.0001)$ in BD. ANOVA revealed no diagnosis related changes of GluR5, GluR7, KA1, and KA2 expression (Table 2, Supplementary Figure S11).

\section{Perirhinal Cortex}

NMDA subunit mRNAs. In situ hybridization studies revealed a common distribution pattern for all NMDA receptor subunits consisting of six isodense bands (Figure 1a-e). Regression analysis of mRNA expression in the 
Table 3 lonotropic Receptor Binding Changes in Medial Temporal Lobe Structures

Tukey HSD post-hoc test

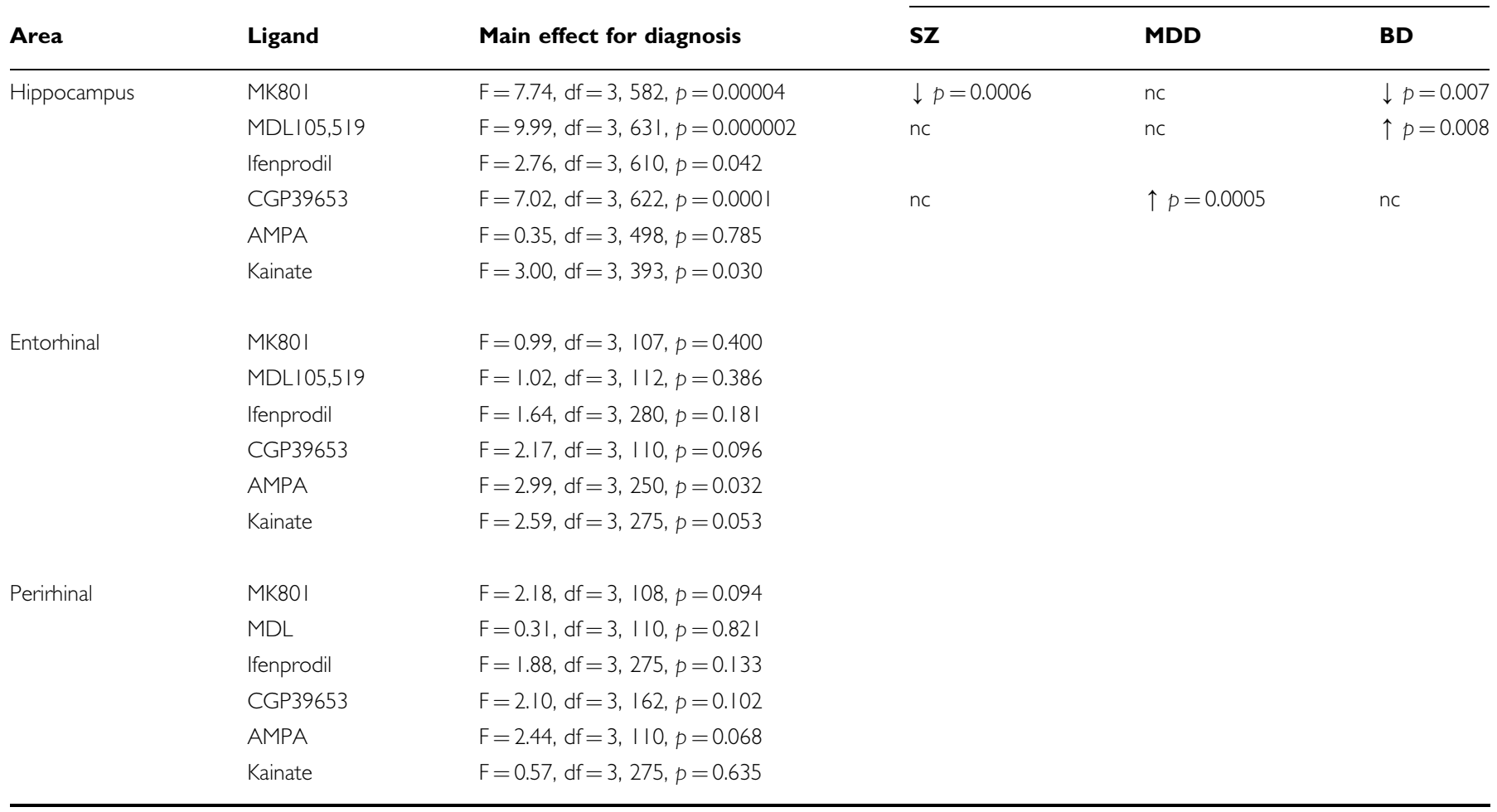

SZ, schizophrenia; MDD, major depressive disorder; BD, bipolar disorder.

perirhinal cortex showed an association between $\mathrm{pH}$ and NR1 $(r=0.34, p=0.01)$ and NR2A expression $(r=0.29$, $p=0.03)$. Using ANCOVA, we detected a main effect for diagnosis for NR1 $(\mathrm{F}=10.82, \mathrm{df}=3,311, p<0.0001)$ and NR2A $(\mathrm{F}=6.44, \mathrm{df}=3,323, p<0.001)$. ANOVA for NR2B showed a main effect for diagnosis $(\mathrm{F}=6.43$, $\mathrm{df}=3,318$, $p<0.001$ ), but no diagnosis by isodense band interactions. Post hoc analysis revealed a significant decrease of NR1 in BD $(p<0.0001)$, NR2A in MDD $(p<0.001)$, and NR2B in both $\mathrm{MDD}(p<0.01)$ and $\mathrm{BD}(p<0.001)$ compared to controls. NR2C and NR2D were not changed (Table 2, Supplementary Figure S12).

AMPA subunit mRNAs. We found seven isodense bands for each of the AMPA receptor subunits detected in the perirhinal cortex (Figure $2 \mathrm{a}-\mathrm{d}$ ). We found an association between GluR2 and PMI $(r=0.30, p=0.02)$. ANCOVA with PMI as covariate revealed no main effect for diagnosis for GluR2. ANOVA of GluR1, GluR3 and GluR4 expression showed a main effect for diagnosis for GluR1 $(\mathrm{F}=13.97$, $\mathrm{df}=3,312, p<0.0001)$ and GluR3 $(\mathrm{F}=6.77, \mathrm{df}=3,318$, $p=0.0002$ ), but no changes for GluR4 expression. Post hoc analysis revealed a decreased GluR1 expression in MDD $(p=0.03)$ and BD $(p<0.0001)$ and decreased GluR3 expression in both mood disorders (MDD: $p=0.01, \mathrm{BD}$ : $p<0.001$ ) (Table 2, Supplementary Figure S13).

Kainate subunit mRNAs. Kainate receptor subunits showed a similar pattern of distribution to AMPA subunits in the perirhinal cortex, characterized by expression in six isodense bands (Figure 3a-e). Regression analysis showed an association between $\mathrm{pH}$ and expression of GluR7 $(r=0.387, p=0.003)$. ANCOVA with $\mathrm{pH}$ as a covariate revealed no main effect for diagnosis for GluR7. ANOVA showed a main effect for diagnosis for GluR5 $(\mathrm{F}=5.6$, $\mathrm{df}=3,324, p<0.001$ ), with no diagnosis by layer interactions. Post hoc analysis showed decreased GluR5 expression in schizophrenia $(p=0.03), \operatorname{MDD}(p=0.002)$, and $\mathrm{BD}$ $(p=0.003)$. No main effect for diagnosis was found for GluR6, KA1, or KA2 expression (Table 2, Supplementary Figure S14).

\section{Receptor Binding Autoradiography}

Specific binding of $\left[{ }^{3} \mathrm{H}\right]$ AMPA, $\left[{ }^{3} \mathrm{H}\right]$ kainate, and four distinct NMDA binding sites $\left(\left[{ }^{3} \mathrm{H}\right] \mathrm{MK}-801\right.$ (intrachannel site), $\left[{ }^{3} \mathrm{H}\right]$ ifenprodil (polyamine site), [ $\left.{ }^{3} \mathrm{H}\right] \mathrm{CGP} 39653$ (glutamate site), and $\left[{ }^{3} \mathrm{H}\right] \mathrm{MDL} 105,519$ (glycine site)) was observed in all of the subdivisions of the hippocampus, and in entorhinal and perirhinal cortices (Figures $4 a-h)$. In the hippocampus, receptor autoradiography revealed distribution patterns different from those seen from in situ hybridization studies of subunits transcripts. Less complex isodense banding patterns were found in the entorhinal and perirhinal cortices for receptor binding when compared to in situ hybridization (compare Figures 1 and 4). Both $\left[{ }^{3} \mathrm{H}\right] \mathrm{AMPA}$ and $\left[{ }^{3} \mathrm{H}\right]$ kainate binding produced higher density bands in deep layers (V and VI) of the cortex, as well as in layer II (Figures 5a and c). Binding sites labeled by NMDA radioligands were more homogeneously expressed through cortical layers (Figure 4). [ $\left.{ }^{3} \mathrm{H}\right] \mathrm{MDL} 105,519$ produced the highest labeling of the NMDA ligands in 

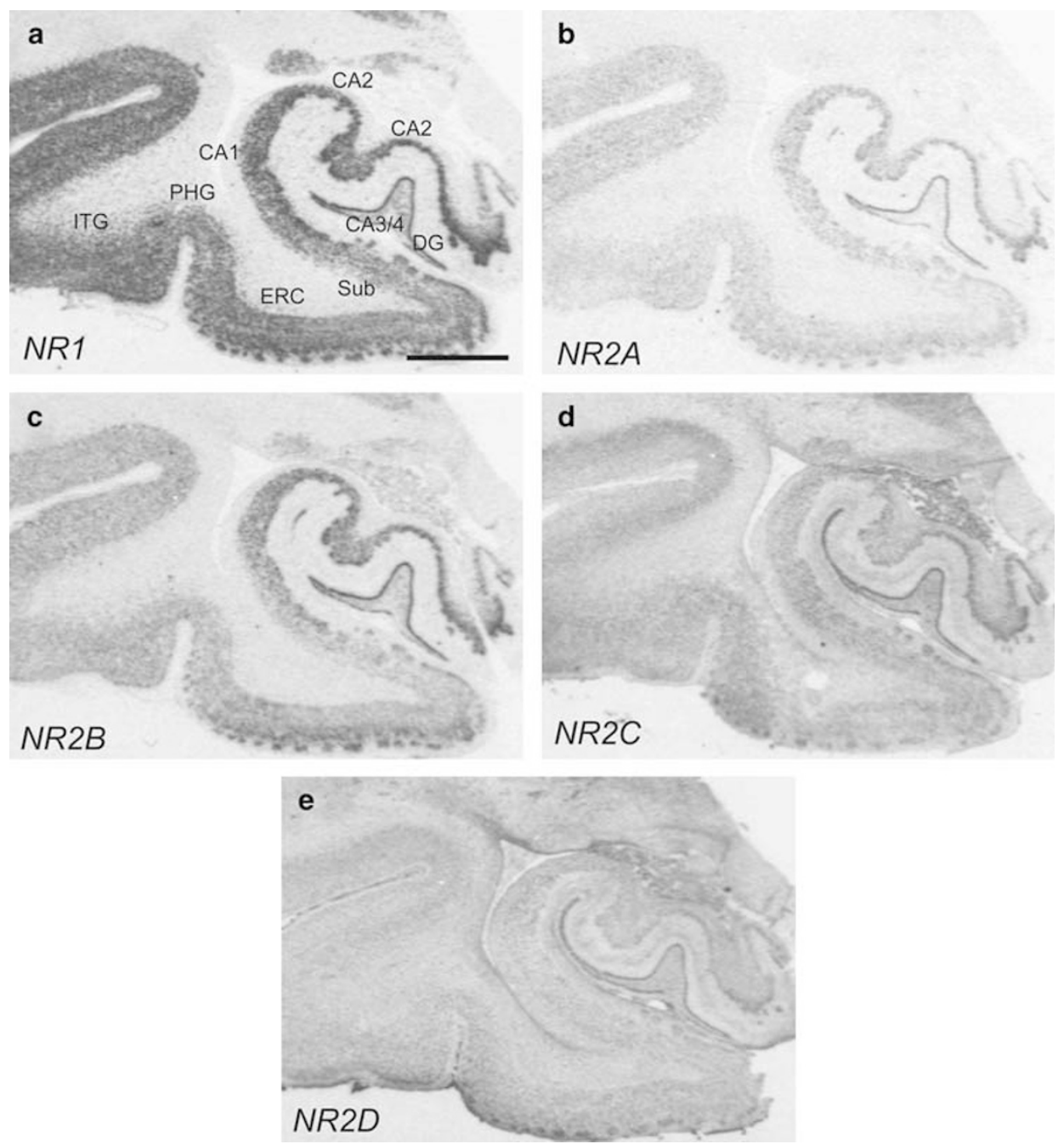

Figure I In situ hybridization using $\left[{ }^{35} \mathrm{~S}\right]$-labeled antisense riboprobes for NMDA receptor subunit transcripts in the medial temporal lobe. CA I-4: Cornu Ammonis CAI-4, DG: dentate gyrus, Sub: subiculum, ERC: entorhinal cortex, PHG: parahippocampal gyrus, ITG: inferior temporal gyrus. Scale bar: 5 mm.

hippocampus, perirhinal and entorhinal cortex, follow by $\left[{ }^{3} \mathrm{H}\right] \mathrm{MK} 801$ (Figures $4 \mathrm{e}$ and $\mathrm{g}$ ).

In the hippocampus, we found an association between $\left[{ }^{3} \mathrm{H}\right]$ ifenprodil binding and PMI $(r=0.4, p<0.003)$ and $\mathrm{pH}$ $(r=0.3, p<0.02)$. Using ANCOVA with PMI and $\mathrm{pH}$ as covariates we did not detect a main effect for diagnosis for $\left[{ }^{3} \mathrm{H}\right]$ ifenprodil binding. Analysis of variance for the other NMDA binding sites showed a main effect for diagnosis $\left(\left[{ }^{3} \mathrm{H}\right] \mathrm{MK}-801\right.$ : $\quad \mathrm{F}=7.74, \quad \mathrm{df}=3,582, \quad p<0.0001$; $\left[{ }^{3} \mathrm{H}\right] \mathrm{MDL} 105,519: \mathrm{F}=9.99,3,631, p<0.0001 ;\left[{ }^{3} \mathrm{H}\right] \mathrm{CGP} 39653$ : $\mathrm{F}=7,02, \mathrm{df}=3,622, p<0.001)$. Post hoc analysis revealed a significant reduction in the hippocampus of $\left[{ }^{3} \mathrm{H}\right] \mathrm{MK}-801$ binding in schizophrenia $(p<0.001)$ and $\mathrm{BD}(p<0.001)$, whereas $\left[{ }^{3} \mathrm{H}\right]$ MDL105,519 binding was increased in BD $(p=0.007)$, and $\left.{ }^{3} \mathrm{H}\right]$ CGP39653 increased in MDD $(p<0.001)$. In the hippocampus, we detected no association of kainate and AMPA receptor binding with PMI, $\mathrm{pH}$, or age. Analysis of variance did not show a main effect for diagnosis for $\left[{ }^{3} \mathrm{H}\right]$ kainate or $\left[{ }^{3} \mathrm{H}\right]$ AMPA expression (Table 3, Supplementary Figure S15).

Receptor autoradiography analysis in the perirhinal and entorhinal cortices revealed no significant changes in the binding of any of the radioligands tested in schizophrenia or the mood disorders (Table 3, Supplementary Figures S16 and S17).

\section{DISCUSSION}

In this study, we found abnormalities in the expression of ionotropic glutamate receptor subunit transcripts in medial temporal cortex in schizophrenia and mood disorders. We observed striking differences between schizophrenia and the mood disorders. The subjects with schizophrenia showed few changes, whereas numerous alterations in the expression of glutamate receptor subunits were found for the mood disorders in the medial temporal cortex. No changes were found for any of the three illnesses in hippocampus, whereas the entorhinal cortex was only affected in BD. Both MDD and BD had robust expression changes of all three ionotropic receptor types in the perirhinal cortex. These results support our hypothesis of altered glutamatergic neurotransmission in the medial temporal lobe in schizophrenia and the mood disorders, 

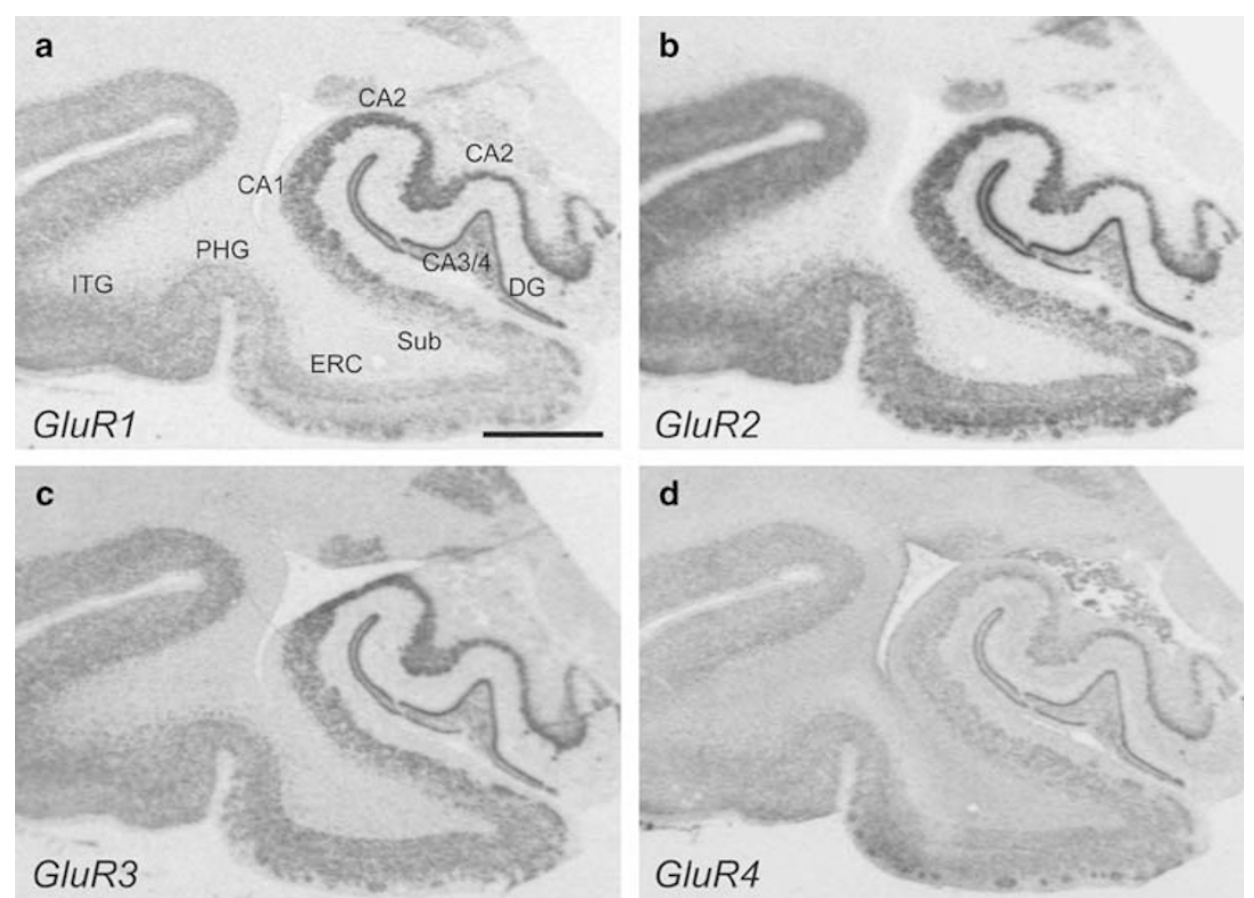

Figure 2 In situ hybridization using $\left[{ }^{35} \mathrm{~S}\right]$-labeled antisense riboprobes for AMPA receptor subunit transcripts in the medial temporal lobe. See Figure I for abbreviations. Scale bar: $5 \mathrm{~mm}$.

and highlight the specific regional distribution of the alterations of glutamate receptor subunit transcripts expression that occur in the mood disorders in the limbic cortex. Some of the results presented in this manuscript appear in a prior meta-analysis by the Stanley Neuropathology Consortium about the molecular abnormalities in the hippocampus in schizophrenia (Knable et al, 2004).

\section{Altered Ionotropic Glutamate Receptor Expression in the Medial Temporal Lobe in Schizophrenia}

The lack of changes in non-NMDA receptor subunits in the hippocampus contrasts with other reports that, although not including NMDA receptor subunit analysis, show that there are alterations in AMPA and kainate subunit transcripts, specifically decreased GluR1 and 2 (Eastwood et al, 1995, 1997), and GluR6 and KA2 (Porter et al, 1997) in the hippocampus in schizophrenia. (Harrison et al, 1991) reported decreased GluR1 mRNA expression in multiple hippocampal regions in schizophrenia (DG, CA3, CA4, and Sub), and decreased GluR2 transcripts in the parahippocampal gyrus. This group performed a second study of mRNA expression of GluR1 and GluR2 flip and flop isoforms, finding that both are decreased in hippocampal structures in schizophrenia (Eastwood et al, 1997). The inconsistencies between our results and these studies, as we did not find differences between regions of the hippocampus, nor any AMPA or kainate expression changes in schizophrenia, might be due to differences in the subject cohorts, or to methodological reasons, such as differences between RT-PCR $v$ s in situ hybridization.

However, we detected changes in $\left[{ }^{3} \mathrm{H}\right] \mathrm{MK} 801$ binding in the hippocampus in schizophrenia. Interestingly, a recent study found that the effects of PCP administration on the firing pattern of neurons in the prefrontal cortex are mediated by afferents from the hippocampus. Studies show that PCP-induced long-lasting activation of the prefrontal cortex plays a pivotal role in the development of behavioral abnormalities comparable to some symptoms of schizophrenia (Moghaddam and Adams, 1998; Suzuki et al, 2002; Jodo et al, 2003; Takahata and Moghaddam, 2003). A recent study identified the hippocampus as a source of PCPinduced excitatory inputs to the prefrontal cortex by a dense glutamatergic projection to the medial prefrontal cortex (Jay et al, 1992; Takahata and Moghaddam, 2003) originated in the ventral hippocampus. Disinhibitory activation of CA1 pyramidal cells can be produced by inhibition of tonic GABA inputs by NMDA antagonists like PCP (Gurguis et al, 1990; Jay et al, 1992). PCP locally infused into the ventral hippocampus increased spontaneous discharges of prefrontal neurons with augmentation of locomotor activity in freely moving rats. Local application of a more selective NMDA receptor antagonist, MK801, to ventral hippocampal neurons under anesthesia increased the spontaneous firing rates of most neurons directly projecting to the medial prefrontal cortex, whereas local application of MK801 to medial prefrontal cortical neurons did not induce excitatory responses in any of those neurons. This suggests that the behavioral abnormalities in schizophrenia might be related to a malfunction of the prefrontal cortex as a response to a change in glutamate neurotransmission in the hippocampus, related to an alteration of NMDA receptors in the postsynaptic hippocampus cells, which is consistent with our present results of decreased MK801 binding in the hippocampus.

Noteworthy, changes in glutamate receptor subunit expression in the temporal cortex in schizophrenia in our current work were also very limited restricted to decreased 

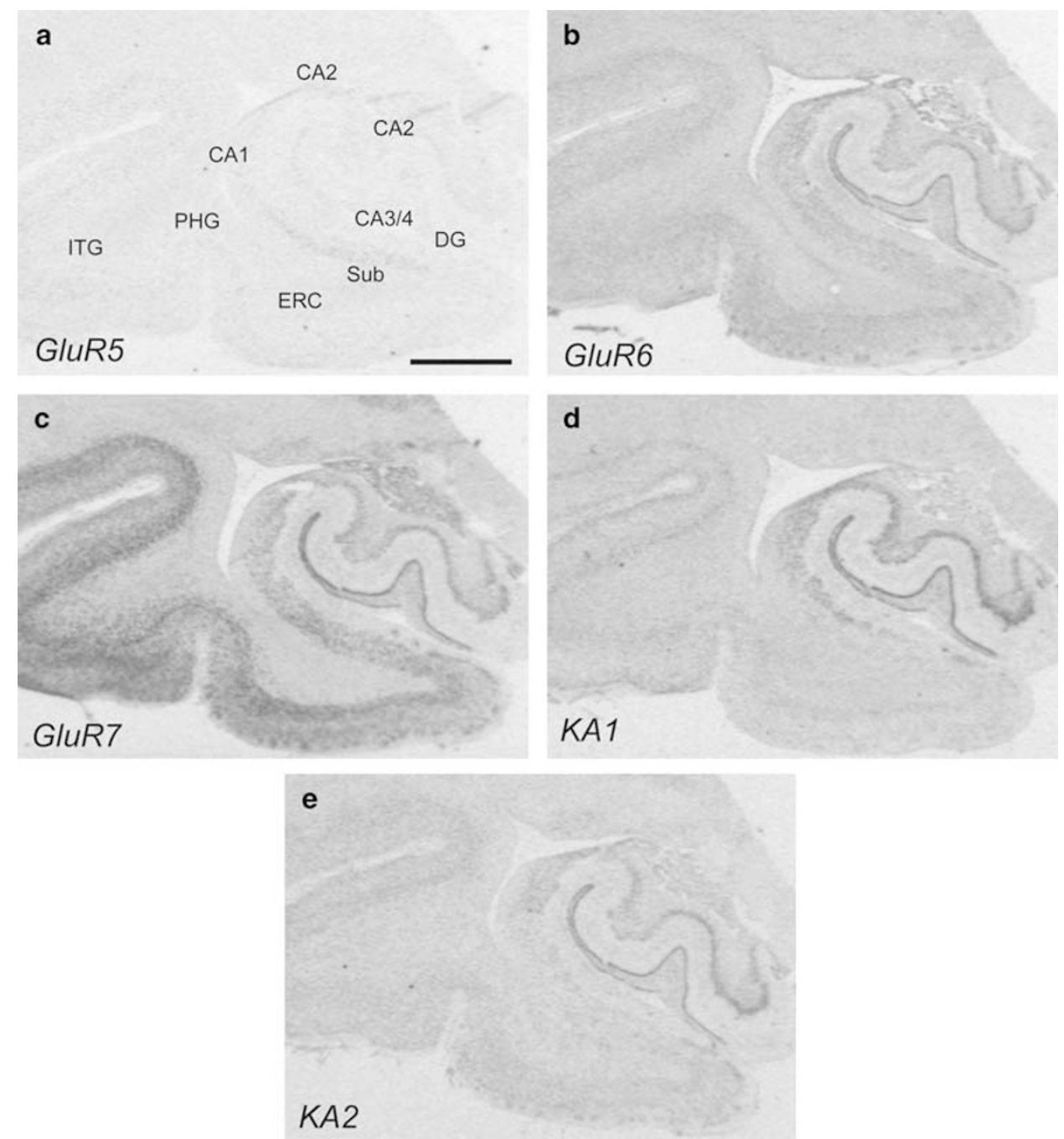

Figure 3 In situ hybridization using $\left[{ }^{35} \mathrm{~S}\right.$-labeled antisense riboprobes for kainate receptor subunit transcripts in the medial temporal lobe. See Figure I for abbreviations. Scale bar: $5 \mathrm{~mm}$.

GluR5 subunit expression in the perirhinal cortex. These data correlate with reports on the expression of this subunit in the dorsolateral prefrontal cortex in schizophrenia by Scarr et al (2005).

\section{Altered Ionotropic Glutamate Receptor Expression in the Medial Temporal Lobe in MDD}

Recent findings indicate that dysfunction of glutamatergic pathways in the brain may be one of the mechanisms involved in the pathophysiology of depression (HerescoLevy and Javitt, 1998). In addition, deficits of NMDA receptors have been found in the frontal cortex of suicide victims (Nowak et al, 1995, 2003). In MDD, we found robust changes in the expression of several key glutamate receptor subunits in the perirhinal cortex. Among the NMDA receptor subunits, expression of NR2A and NR2B transcripts were drastically reduced.

The differential expression of NR2 subunits during brain development has been proposed to reflect not only maturational changes, but to have physiological roles in the nervous system (Komuro and Rakic, 1993; Sucher et al, 1995; Behar et al, 1999; Ikonomidou et al, 1999). Depending on their subunit composition, NMDA receptors have different electrophysiological properties (Monyer et al, 1994; Sucher et al, 1995). For example, receptors composed of NR1/NR2A subunits show the fastest and NR1/NR2D show the slowest deactivation kinetics. The $\mathrm{Mg}^{2+}$ blockade is different among receptors with different subunit composition, where only NMDA receptors containing NR2A or NR2B subunits are blocked. In our results in the perirhinal cortex, we detected decreased expression of these two subunits in MDD, suggesting a reduction in the probability of $\mathrm{Mg}^{2+}$ blockade of NMDA receptors.

Recently, some studies have focused on the importance of NMDA receptor subunit composition and signaling at the postsynaptic cell. Biochemical studies have shown highaffinity binding between the catalytic domain of CaMKII and the C-tail of NR2B subunit of the NMDA receptor (Strack and Colbran, 1998; Leonard et al, 1999; Strack et al, 2000; Bayer et al, 2001; Mayadevi et al, 2002). Many brain regions, including the hippocampus, show changes from 
a
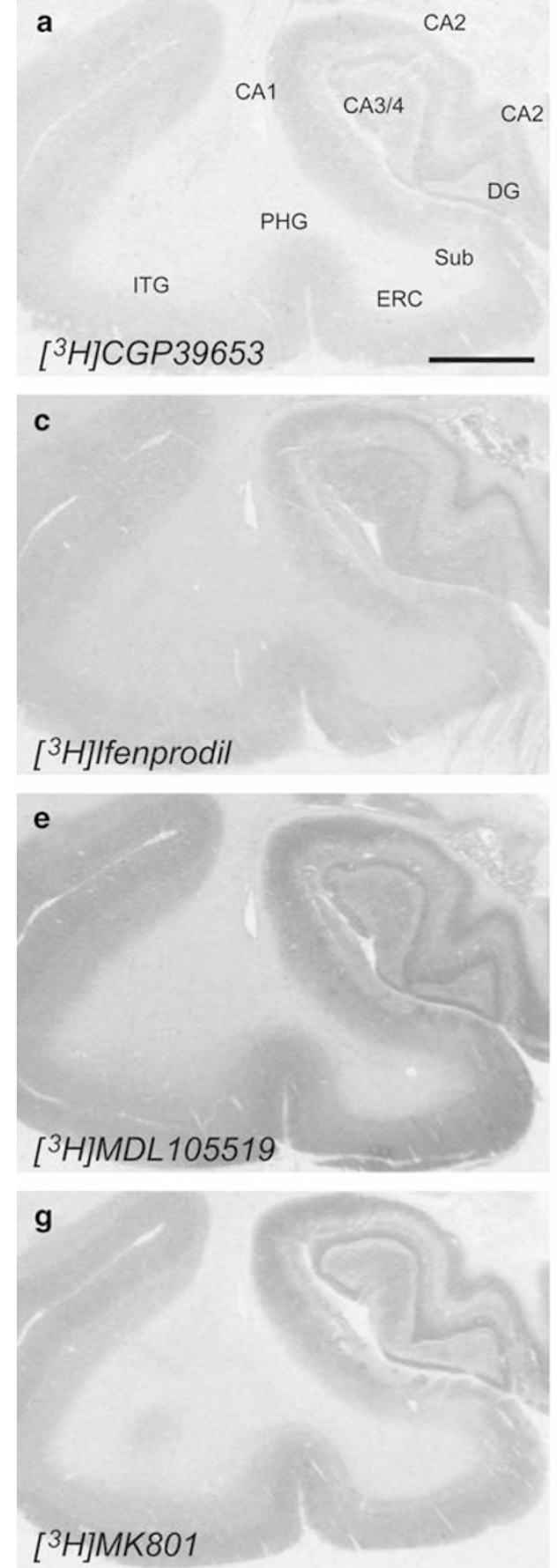

b

G

d

f

h

Figure 4 NMDA receptor autoradiography in the medial temporal lobe. b, d, f, and h: non-specific binding in the presence of blockers for each ligand. See Figure I for abbreviations. Scale bar: $5 \mathrm{~mm}$.

containing predominantly NR2B to containing NR2A in response to different stimuli (Monyer et al, 1994; Sheng et al, 1994). This change can be driven by activity (Barria and Malinow, 2002), experience (Quinlan et al, 1999; Philpot et al, 2001; Mierau et al, 2004), or learning (Quinlan et al, 2004). In mature animals, some brain regions (eg, the hippocampus) contain predominantly NR2A, and both NR2A and NR2B NMDA receptor subunits play important roles in LTP (Sakimura et al, 1995; Ito et al, 1996; Kim et al, 2005). Interestingly, it has been shown that acute replace- ment of synaptic NR2B with NR2A decreases LTP and spontaneous activity-driven potentiation characterized by a drive of AMPA receptor into synapses (Zhu and Malinow, 2002; Barria and Malinow, 2005), as do mutations of NR2B that prevent association to active CaMKII (Barria and Malinow, 2005). An association between active CaMKII and NR2B has been shown for some forms of activity-driven synaptic potentiation by AMPA receptor trafficking to the membrane. Our results of lower expression of both NR2A and NR2B transcripts in MDD suggest a possible compro- 

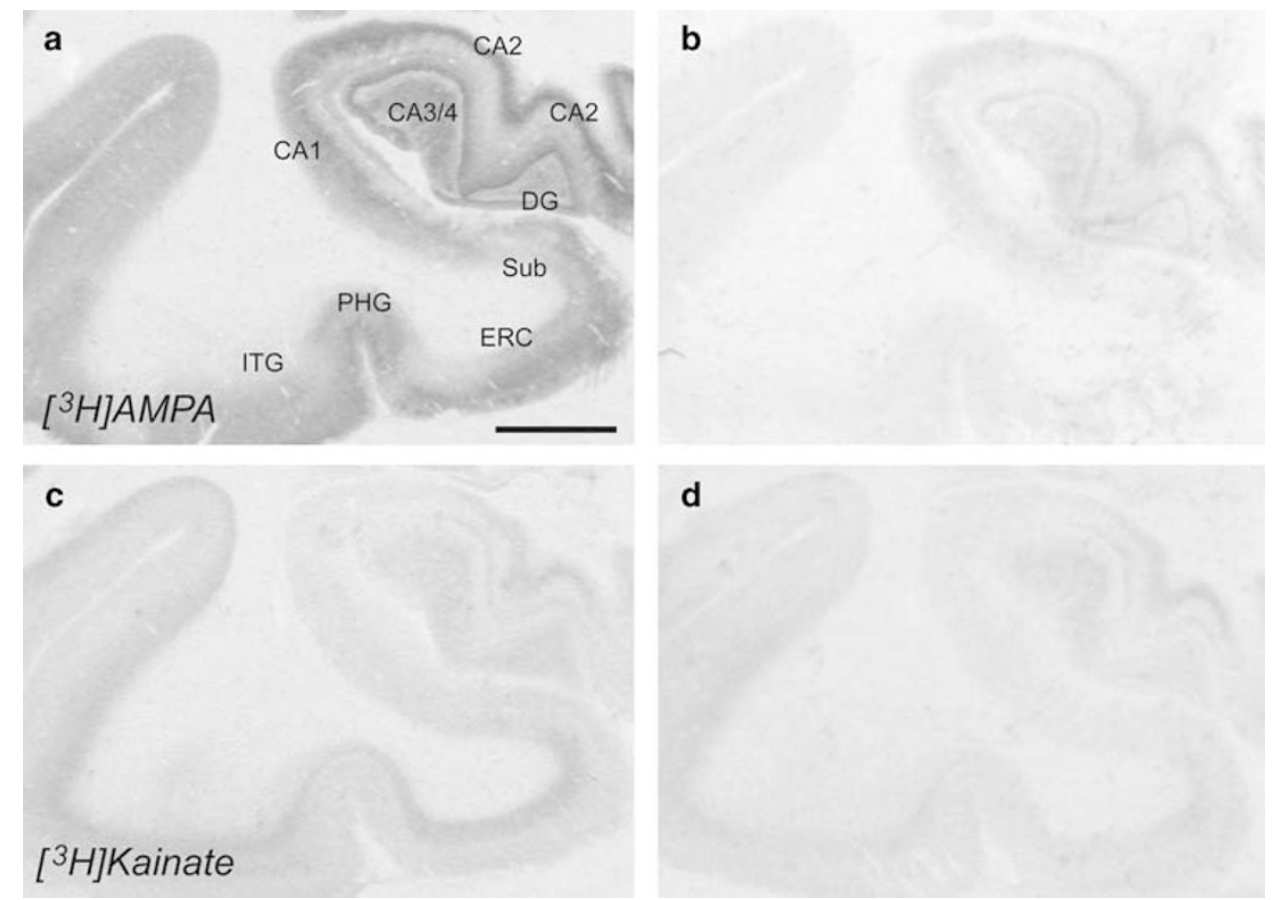

d

Figure 5 AMPA and kainate receptor autoradiography in the medial temporal lobe. $b$ and d: non-specific $\left[{ }^{3} \mathrm{H}\right] \mathrm{AMPA}$ and $\left[{ }^{3} \mathrm{H}\right] \mathrm{kainate}$ binding in the presence of CNQX. See Figure I for abbreviations. Scale bar: $5 \mathrm{~mm}$.

mise in LTP and, consequently, in AMPA receptor trafficking to hippocampal synapses. Studies of activation of CaMKII and trafficking of AMPA receptors in the hippocampus in MDD would be needed to support that hypothesis.

GluR1 and GluR3 AMPA receptors also showed lower expression in MDD compared to controls. These two subunits bind to specific intracellular proteins that mediate two of the AMPA trafficking pathways at the postsynaptic density. It has been suggested that GluR1 is the subunit providing the 'driving force' for activity-dependent synaptic delivery of AMPA receptors, whereas GluR2/3 mediate the constitutive recycling and regulated endocytosis of AMPA receptors. SAP97 is required for the trafficking of newly synthesized GluR1-containing AMPA receptors in response to increased synaptic activation. The decreased expression of GluR1 in the perirhinal cortex in MDD could compromise the fast trafficking of AMPA receptors from the Golgi to the postsynaptic membrane in cellular mechanisms like LTP (Esteban, 2003). The downregulation of GluR3 also suggests that the rapid recycling and/or storage in the trafficking pathway involving GluR2/3 might be disrupted in MDD.

\section{Abnormal Ionotropic Glutamate Receptor Expression in the Medial Temporal Lobe in BD}

As in MDD, no alterations in mRNA expression in the hippocampus were seen in BD. However, changes in glutamate receptor expression in medial temporal cortices were found, and contrasting with MDD, changes were also present in the entorhinal cortex. GluR1 transcripts were downregulated in the perirhinal cortex but not in the entorhinal, GluR2 reduced only in the entorhinal, whereas GluR3 had reduced expression in both areas. As explained before for the changes found in MDD, alterations on the expression of AMPA subunits suggest that trafficking of the AMPA receptors mediated by them. Abnormal trafficking of AMPA receptors towards the cell membrane could affect activation of NMDA receptors. In this case, we also found a decrease in GluR2 expression maybe as a compensatory effect to overcome the lower concentration of intracellular $\mathrm{Ca}^{+2}$ owing to the lower activation of NMDA receptors. This hypothesis is also supported by the reduction in the expression of GluR3 in both cortical areas, as GluR3 mediates the recycling of AMPA receptors regulated by NMDA activation.

Similar to our finding in schizophrenia, in BD we found a significant decrease in $\left[{ }^{3} \mathrm{H}\right] \mathrm{MK}-801$ binding in the hippocampus, consistent with a recent report that also found a significant decrease in $\left[{ }^{3} \mathrm{H}\right] \mathrm{MK}-801$ binding in CA3 and the Sub (Scarr et al, 2003). As described above, this finding suggests an alteration in the quantity and activity of NMDA receptors in hippocampal neurons that could impact hippocampal connectivity with the prefrontal cortex and might contribute to behavioral abnormalities in this illness. We also found an increase in $\left[{ }^{3} \mathrm{H}\right] \mathrm{MDL} 105,519$ binding in the hippocampus in $\mathrm{BD}$, indicating an increase in the number of NMDA-receptor containing glycine binding sites in this region. The MK-801 and glycine NMDA receptor binding sites preferentially bind NR2A-B and NR1-containing NMDA receptors, respectively (Lynch et al, 1994). However, we did not find any changes in NR1, NR2A, or $\mathrm{NR} 2 \mathrm{~B}$ transcript expression in the hippocampus in $\mathrm{BD}$, results that are inconsistent with either a change in NMDA receptor stoichiometry or a change in the total number of 
receptors. One explanation for these divergent results is that there are changes in NMDA receptor subunit protein levels that are not reflected at the level of transcript expression. Alternatively, there may be divergent changes in subsets of neurons expressing NMDA receptor subunits and binding sites. As our experimental techniques only permit regional level analyses, we would not have detected changes in expression in different subsets of cells.

The entorhinal cortex is a crucial component of the medial temporal lobe memory system (Scoville and Milner, 1957; Squire and Zola-Morgan, 1991). Layer V neurons of the entorhinal cortex receive convergent sensory input from other cortical areas (Room and Groenewegen, 1986; Rempel-Clower and Barbas, 2000), give rise to a massive projection to the cerebral cortex, including the dorsolateral prefrontal cortex (Insausti et al, 1997), and are the target of hippocampal output (Nussenzveig et al, 1991). The changes we detected in the entorhinal and perirhinal cortices might represent a disruption in glutamatergic neurotransmission in these cortical areas as postsynaptic targets of prefrontal or hippocampal input, or of transcripts destined to presynaptic terminals from the projections they send back to the cortex or hippocampus.

\section{Limitations of the Study}

Several limitations need to be considered when interpreting data from these studies. First, an important limitation of this and all postmortem studies in psychiatric illness is the possible confounding effect of psychotropic medications. The majority of patients with schizophrenia and mood disorders from this study were exposed to psychotropic drugs at some point in life (Torrey et al, 2000). Antipsychotic medications can modulate early gene expression (Deutch et al, 1995; Cohen and Wan, 1996; Holcomb et al, 1996). They do not, however, appear to affect thalamic NMDA receptor expression (Ulas et al, 1993). Dracheva et al (2001) reported altered NMDA receptor subunit expression in the prefrontal and occipital cortices in schizophrenia, and found that these transcripts did not differ between patients that were taking antipsychotic medication within 6 weeks of death and those that were medication-free for greater than 6 weeks (Dracheva et al, 2001). Less is known about the effects of antidepressants and mood stabilizers on the expression of glutamate receptors. One study showed that antidepressant agents reduce transcript expression for some NMDA receptor subunits in the thalamus, cortex, cerebellum, and striatum of mouse (Boyer et al, 1998). Although other work indicates that mood stabilizers like lithium can influence NMDA receptor function (Chuang et al, 2002; Hashimoto et al, 2002), no studies to date have examined the effect of these agents on the expression of glutamate receptors.

Another limitation of this study is that our receptor subunit transcript expression data and our receptor binding data are not consistent with one another. As changes in binding site expression generally reflect changes in receptor subunit stoichiometry, one would expect to find some changes in subunit mRNA expression in instances where there are changes in binding site expression. Possible explanations for these discrepancies include (1) we did not have sufficient power to detect small changes in mRNA expression, or (2) changes in receptor subunit expression are not evident at the transcript level, but might be detected at the protein level. The protein levels are determined not only by the level of the mRNA that codifies it and its translation rate, but also by the folding efficiency of the protein itself, posttranslational modifications, binding with other components to form protein complexes, and the rate of protein degradation. Some of these events could modify protein levels without a change in mRNA expression (You and Yin, 2000; Kristiansen et al, 2006).

In summary, our data support that in schizophrenia and mood disorders, glutamate receptor expression is altered in the medial temporal lobe. However, all three illnesses, but most remarkably schizophrenia and $\mathrm{BD}$, have a unique distribution of glutamatergic alterations. Although we propose that compromised glutamate-mediated synaptic neurotransmission in these limbic areas might be an important component of the pathophysiology of schizophrenia and the mood disorders, the regional heterogeneity of these alterations might explain the dissimilarity of symptoms between schizophrenia and mood disorders. Although glutamate abnormalities in schizophrenia are characterized for their major neocortical, thalamic, and striatal components (some also shared by $\mathrm{BD}$ ), the present data suggest that glutamatergic abnormalities in $\mathrm{BD}$ can be further typified by a parahippocampal cortical location (entorhinal and perirhinal cortices), previously suggested to be responsible for the deficits found in working memory and attention (Adler et al, 2004).

\section{ACKNOWLEDGEMENTS}

This work was supported by MH53327 (JHM-W). We acknowledge the technical assistance of Alan J Hogg and Smriti M Agrawal PhD. Postmortem brains were donated by The Stanley Medical Research Institute's Brain Collection courtesy of Drs Michael B Knable, E Fuller Torrey, Maree J Webster, Serge Weis, and Robert H Yolken.

\section{REFERENCES}

Adler CM, Holland SK, Schmithorst V, Tuchfarber MJ, Strakowski SM (2004). Changes in neuronal activation in patients with bipolar disorder during performance of a working memory task. Bipolar Disord 6: 540-549.

Arnold SE (1997). The medial temporal lobe in schizophrenia. J Neuropsychiatry Clin Neurosci 9: 460-470.

Baron BM, Siegel BW, Harrison BL, Gross RS, Hawes C, Towers P (1996). [ $\left.{ }^{3} \mathrm{H}\right] \mathrm{MDL} 105,519$, a high-affinity radioligand for the $\mathrm{N}$ methyl-D-aspartate receptor-associated glycine recognition site. J Pharmacol Exp Ther 279: 62-68.

Barria A, Malinow R (2002). Subunit-specific NMDA receptor trafficking to synapses. Neuron 35: 345-353.

Barria A, Malinow R (2005). NMDA receptor subunit composition controls synaptic plasticity by regulating binding to CaMKII. Neuron 48: 289-301.

Bayer KU, De Koninck P, Leonard AS, Hell JW, Schulman H (2001). Interaction with the NMDA receptor locks CaMKII in an active conformation. Nature 411: 801-805.

Bear M, Abraham W (1996). Long-term depression in the hippocampus. Annu Rev Neurosci 19: 437-462.

Bear M, Rittenhouse C (1999). Molecular basis for induction of ocular dominance plasticity. J Neurobiol 41: 83-91. 
Behar T, Scott C, Greene C, Wen X, Smith S, Maric D et al (1999). Glutamate acting at NMDA receptors stimulates embryonic cortical neuronal migration. J Neurosci 19: 4449-4461.

Benes FM (1999). Evidence for altered trisynaptic circuitry in schizophrenic hippocampus. Biol Psychiatry 46: 589-599.

Benes FM, Kwok EW, Vincent SL, Todtenkopf MS (1998). A reduction of nonpyramidal cells in sector CA2 of schizophrenics and manic depressives. Biol Psychiatry 44: 88-97.

Bertolino A, Callicott JH, Elman I, Mattay VS, Tedeschi G, Frank JA et al (1998). Regionally specific neuronal pathology in untreated patients with schizophrenia: a proton magnetic resonance spectroscopic imaging study. Biol Psychiatry 43: 641-648.

Bertolino A, Nawroz S, Mattay VS, Barnett AS, Duyn JH, Moonen CT et al (1996). Regionally specific pattern of neurochemical pathology in schizophrenia as assessed by multislice proton magnetic resonance spectroscopic imaging. Am J Psychiatry 153: 1554-1563.

Bliss TV, Collingridge GL (1993). A synaptic model of memory: long-term potentiation in the hippocampus. Nature 361: 31-39.

Bogerts B, Ashtari M, Degreef G, Alvir JM, Bilder RM, Lieberman JA (1990a). Reduced temporal limbic structure volumes on magnetic resonance images in first episode schizophrenia. Psychiatry Res 35: 1-13.

Bogerts B, Falkai P, Haupts M, Greve B, Ernst S, Tapernon-Franz U et al (1990b). Post-mortem volume measurements of limbic system and basal ganglia structures in chronic schizophrenics. Initial results from a new brain collection. Schizophr Res 3: 295-301.

Boyer PA, Skolnick P, Fossom LH (1998). Chronic administration of imipramine and citalopram alters the expression of NMDA receptor subunit mRNAs in mouse brain. A quantitative in situ hybridization study. J Mol Neurosci 10: 219-233.

Chuang DM, Chen RW, Chalecka-Franaszek E, Ren M, Hashimoto $\mathrm{R}$, Senatorov V et al (2002). Neuroprotective effects of lithium in cultured cells and animal models of diseases. Bipolar Disord 4: 129-136.

Cohen B, Wan W (1996). The thalamus as a site of action of antipsychotic drugs. Am J Psychiatry 153: 104-106.

Coyle JT (1996). The glutamatergic dysfunction hypothesis for schizophrenia. Harv Rev Psychiatry 3: 241-253.

Csernansky JG, Wang L, Jones D, Rastogi-Cruz D, Posener JA, Heydebrand G et al (2002). Hippocampal deformities in schizophrenia characterized by high dimensional brain mapping. Am J Psychiatry 159: 2000-2006.

Deicken RF, Pegues M, Amend D (1999). Reduced hippocampal $\mathrm{N}$-acetylaspartate without volume loss in schizophrenia. Schizophr Res 37: 217-223.

Deutch A, Ongur D, Duman R (1995). Antipsychotic drugs induce Fos protein in the thalamic paraventricular nucleus: a novel antipsychotic drug action. Neuroscience 66: 337-346.

Dracheva S, Marras SA, Elhakem SL, Kramer FR, Davis KL, Haroutunian V (2001). N-methyl-D-aspartic acid receptor expression in the dorsolateral prefrontal cortex of elderly patients with schizophrenia. Am J Psychiatry 158: 1400-1410.

Eastwood SL, Burnet PW, Harrison PJ (1997). GluR2 glutamate receptor subunit flip and flop isoforms are decreased in the hippocampal formation in schizophrenia: a reverse transcriptase-polymerase chain reaction (RT-PCR) study. Brain Res Mol Brain Res 44: 92-98.

Eastwood SL, McDonald B, Burnet PW, Beckwith JP, Kerwin RW, Harrison PJ (1995). Decreased expression of mRNAs encoding non-NMDA glutamate receptors GluR1 and GluR2 in medial temporal lobe neurons in schizophrenia. Brain Res Mol Brain Res 29: 211-223.

Esteban JA (2003). AMPA receptor trafficking: a road map for synaptic plasticity. Mol Interv 3: 375-385.

Friston KJ, Liddle PF, Frith CD, Hirsch SR, Frackowiak RS (1992). The left medial temporal region and schizophrenia. A PET study. Brain 115(Part 2): 367-382.
Gao XM, Sakai K, Roberts RC, Conley RR, Dean B, Tamminga CA (2000). Ionotropic glutamate receptors and expression of $\mathrm{N}$ methyl-D-aspartate receptor subunits in subregions of human hippocampus: effects of schizophrenia. Am J Psychiatry 157: 1141-1149.

Gurguis GN, Meador-Woodruff JH, Haskett RF, Greden JF (1990). Multiplicity of depressive episodes: phenomenological and neuroendocrine correlates. Biol Psychiatry 27: 1156-1164.

Harrison PJ (1999). The neuropathology of schizophrenia. A critical review of the data and their interpretation. Brain 122(Part 4): 593-624.

Harrison PJ, Eastwood SL (2001). Neuropathological studies of synaptic connectivity in the hippocampal formation in schizophrenia. Hippocampus 11: 508-519.

Harrison PJ, McLaughlin D, Kerwin RW (1991). Decreased hippocampal expression of a glutamate receptor gene in schizophrenia. Lancet 337: 450-452.

Hashimoto K, Mantione CR, Spada MR, Neumeyer JL, London ED (1994). Further characterization of $\left[{ }^{3} \mathrm{H}\right]$ ifenprodil binding in rat brain. Eur J Pharmacol 266: 67-77.

Hashimoto R, Takei N, Shimazu K, Christ L, Lu B, Chuang DM (2002). Lithium induces brain-derived neurotrophic factor and activates TrkB in rodent cortical neurons: an essential step for neuroprotection against glutamate excitotoxicity. Neuropharmacology 43: 1173-1179.

Healy DJ, Haroutunian V, Powchik P, Davidson M, Davis KL, Watson SJ et al (1998). AMPA receptor binding and subunit mRNA expression in prefrontal cortex and striatum of elderly schizophrenics. Neuropsychopharmacology 19: 278-286.

Healy DJ, Meador-Woodruff JH (1999). Ionotropic glutamate receptor modulation of 5-HT6 and 5-HT7 mRNA expression in rat brain. Neuropsychopharmacology 21: 341-351.

Heckers S, Konradi C (2002). Hippocampal neurons in schizophrenia. J Neural Transm 109: 891-905.

Heresco-Levy U, Javitt DC (1998). The role of $N$-methyl-Daspartate (NMDA) receptor-mediated neurotransmission in the pathophysiology and therapeutics of psychiatric syndromes. Eur Neuropsychopharmacol 8: 141-152.

Hertzmann M, Reba RC, Kotlyarov EV (1990). Single photon emission computed tomography in phencyclidine and related drug abuse. Am J Psychiatry 147: 255-256.

Holcomb H, Cascella N, Thaker G, Medoff D, Dannals R, Tamminga C (1996). Funcitonal sites of neuroleptic drug action in the human brain: PET/FDG studies with and without haloperidol. Am J Psychiatry 153: 41-49.

Huettner JE, Bean BP (1988). Block of $N$-methyl-D-aspartateactivated current by the anticonvulsant MK-801: selective binding to open channels. Proc Natl Acad Sci USA 85: 1307-1311.

Ibrahim H, Healy D, Hogg AJ, Meador-Woodruff J (2000a). Nucleus-specific expression of ionotropic glutamate receptor subunit mRNAs and binding sites in primate thalamus. Brain Research. Mol Brain Res 79: 1-17.

Ibrahim HM, Hogg Jr AJ, Healy DJ, Haroutunian V, Davis KL, Meador-Woodruff $\mathrm{JH}$ et al (2000b). Ionotropic glutamate receptor binding and subunit mRNA expression in thalamic nuclei in schizophrenia. Am J Psychiatry 157: 1811-1823.

Ikonomidou C, Bosch F, Miksa M, Bittigau P, Vockler J, Dikranian $\mathrm{K}$ et al (1999). Blockade of NMDA receptors and apoptotic neurodegeneration in the developing brain. Science 283: 70-74.

Insausti R, Herrero MT, Witter MP (1997). Entorhinal cortex of the rat: cytoarchitectonic subdivisions and the origin and distribution of cortical efferents. Hippocampus 7: 146-183.

Isaac JT, Nicoll RA, Malenka RC (1995). Evidence for silent synapses: implications for the expression of LTP. Neuron 15: 427-434.

Ito I, Sakimura K, Mishina M, Sugiyama H (1996). Age-dependent reduction of hippocampal LTP in mice lacking $N$-methyl-Daspartate receptor epsilon 1 subunit. Neurosci Lett 203: 69-71. 
Jay TM, Thierry AM, Wiklund L, Glowinski J (1992). Excitatory amino acid pathway from the hippocampus to the prefrontal cortex. Contribution of AMPA receptors in hippocampoprefrontal cortex transmission. Eur J Neurosci 4: 1285-1295.

Jiang L, Xu J, Nedergaard M, Kang J (2001). A kainate receptor increases the efficacy of GABAergic synapses. Neuron 30: 503-513.

Jodo E, Suzuki Y, Takeuchi S, Niwa S, Kayama Y (2003). Different effects of phencyclidine and methamphetamine on firing activity of medial prefrontal cortex neurons in freely moving rats. Brain Res 962: 226-231.

Joyal CC, Laakso MP, Tiihonen J, Syvalahti E, Vilkman H, Laakso A et al (2002). A volumetric MRI study of the entorhinal cortex in first episode neuroleptic-naive schizophrenia. Biol Psychiatry 51: 1005-1007.

Kharazia VN, Phend KD, Rustioni A, Weinberg RJ (1996). EM colocalization of AMPA and NMDA receptor subunits at synapses in rat cerebral cortex. Neurosci Lett 210: 37-40.

Kim MJ, Dunah AW, Wang YT, Sheng M (2005). Differential roles of NR2A- and NR2B-containing NMDA receptors in Ras-ERK signaling and AMPA receptor trafficking. Neuron 46: 745-760.

Knable MB, Barci BM, Webster MJ, Meador-Woodruff J, Torrey EF (2004). Molecular abnormalities of the hippocampus in severe psychiatric illness: postmortem findings from the Stanley Neuropathology Consortium. Mol Psychiatry 9: 544.

Komuro H, Rakic P (1993). Modulation of neuronal migration by NMDA receptors. Science 260: 95-97.

Kristiansen LV, Beneyto M, Haroutunian V, Meador-Woodruff JH (2006). Changes in NMDA receptor subunits and interacting PSD proteins in dorsolateral prefrontal and anterior cingulate cortex indicate abnormal regional expression in schizophrenia. Mol Psychiatry 11: 737-747.

Law AJ, Deakin JF (2001). Asymmetrical reductions of hippocampal NMDAR1 glutamate receptor mRNA in the psychoses. Neuroreport 12: 2971-2974.

Lawrie SM, Abukmeil SS (1998). Brain abnormality in schizophrenia. A systematic and quantitative review of volumetric magnetic resonance imaging studies. $\mathrm{Br} J$ Psychiatry 172: 110-120.

Lawrie SM, Whalley H, Kestelman JN, Abukmeil SS, Byrne M, Hodges A et al (1999). Magnetic resonance imaging of brain in people at high risk of developing schizophrenia. Lancet 353: 30-33.

Leonard AS, Lim IA, Hemsworth DE, Horne MC, Hell JW (1999). Calcium/calmodulin-dependent protein kinase II is associated with the N-methyl-D-aspartate receptor. Proc Natl Acad Sci USA 96: 3239-3244.

Linden DJ, Connor JA (1995). Long-term synaptic depression. Annu Rev Neurosci 18: 319-357.

Lynch DR, Anegawa NJ, Verdoorn T, Pritchett DB (1994). Nmethyl-D-aspartate receptors: different subunit requirements for binding of glutamate antagonists, glycine antagonists, and channel-blocking agents. Mol Pharmacol 45: 540-545.

Maier M, Ron MA, Barker GJ, Tofts PS (1995). Proton magnetic resonance spectroscopy: an in vivo method of estimating hippocampal neuronal depletion in schizophrenia. Psychol Med 25: 1201-1209.

Malenka RC, Nicoll RA (1999). Long-term potentiation-a decade of progress? Science 285: 1870-1874.

Mayadevi M, Praseeda M, Kumar KS, Omkumar RV (2002). Sequence determinants on the NR2A and NR2B subunits of NMDA receptor responsible for specificity of phosphorylation by CaMKII. Biochim Biophys Acta 1598: 40-45.

Medoff DR, Holcomb HH, Lahti AC, Tamminga CA (2001). Probing the human hippocampus using rCBF: contrasts in schizophrenia. Hippocampus 11: 543-550.

Mierau SB, Meredith RM, Upton AL, Paulsen O (2004). Dissociation of experience-dependent and -independent changes in excitatory synaptic transmission during development of barrel cortex. Proc Natl Acad Sci USA 101: 15518-15523.

Miller JA (1991). The calibration of 35S of 32P with 14C-labeled brain paste or 14C-plastic standards for quantitative autoradiography using LKB Ultrofilm or Amersham Hyperfilm. Neurosci Lett 121: 211-214.

Moghaddam B, Adams BW (1998). Reversal of phencyclidine effects by a group II metabotropic glutamate receptor agonist in rats. Science 281: 1349-1352.

Monyer H, Burnashev N, Laurie DJ, Sakmann B, Seeburg PH (1994). Developmental and regional expression in the rat brain and functional properties of four NMDA receptors. Neuron 12: 529-540.

Nelson MD, Saykin AJ, Flashman LA, Riordan HJ (1998). Hippocampal volume reduction in schizophrenia as assessed by magnetic resonance imaging: a meta-analytic study. Arch Gen Psychiatry 57: 433-440.

Nicoll RA, Malenka RC (1995). Contrasting properties of two forms of long-term potentiation in the hippocampus. Nature 377: $115-118$.

Nowak G, Ordway GA, Paul IA (1995). Alterations in the N-methylD-aspartate (NMDA) receptor complex in the frontal cortex of suicide victims. Brain Res 675: 157-164.

Nowak G, Szewczyk B, Sadlik K, Piekoszewski W, Trela F, Florek E et al (2003). Reduced potency of zinc to interact with NMDA receptors in hippocampal tissue of suicide victims. Pol $\mathrm{J}$ Pharmacol 55: 455-459.

Nussenzveig IZ, Sircar R, Wong ML, Frusciante MJ, Javitt DC, Zukin SR (1991). Polyamine effects upon $N$-methyl-D-aspartate receptor functioning: differential alteration by glutamate and glycine site antagonists. Brain Res 561: 285-291.

Pantelis C, Velakoulis D, McGorry PD, Wood SJ, Suckling J, Phillips LJ et al (2003). Neuroanatomical abnormalities before and after onset of psychosis: a cross-sectional and longitudinal MRI comparison. Lancet 361: 281-288.

Philpot BD, Weisberg MP, Ramos MS, Sawtell NB, Tang YP, Tsien JZ et al (2001). Effect of transgenic overexpression of NR2B on NMDA receptor function and synaptic plasticity in visual cortex. Neuropharmacology 41: 762-770.

Porter RH, Eastwood SL, Harrison PJ (1997). Distribution of kainate receptor subunit mRNAs in human hippocampus, neocortex and cerebellum, and bilateral reduction of hippocampal GluR6 and KA2 transcripts in schizophrenia. Brain Res 751: 217-231.

Quinlan EM, Lebel D, Brosh I, Barkai E (2004). A molecular mechanism for stabilization of learning-induced synaptic modifications. Neuron 41: 185-192.

Quinlan EM, Philpot BD, Huganir RL, Bear MF (1999). Rapid, experience-dependent expression of synaptic NMDA receptors in visual cortex in vivo. Nat Neurosci 2: 352-357.

Rajkowska G (2002a). Cell pathology in bipolar disorder. Bipolar Disord 4: 105-116.

Rajkowska G (2002b). Cell pathology in mood disorders. Semin Clin Neuropsychiatry 7: 281-292.

Ransom RW, Stec NL (1988). Cooperative modulation of $\left[{ }^{3} \mathrm{H}\right] \mathrm{MK}-$ 801 binding to the $N$-methyl-D-aspartate receptor-ion channel complex by L-glutamate, glycine, and polyamines. J Neurochem 51: $830-836$.

Rempel-Clower NL, Barbas H (2000). The laminar pattern of connections between prefrontal and anterior temporal cortices in the Rhesus monkey is related to cortical structure and function. Cereb Cortex 10: 851-865.

Room P, Groenewegen HJ (1986). Connections of the parahippocampal cortex. I. cortical afferents. J Comp Neurol 251: 415-450.

Sakimura K, Kutsuwada T, Ito I, Manabe T, Takayama C, Kushiya E et al (1995). Reduced hippocampal LTP and spatial learning in mice lacking NMDA receptor epsilon 1 subunit. Nature 373: 151-155. 
Scarr E, Beneyto M, Meador-Woodruff JH, Deans B (2005). Cortical glutamatergic markers in schizophrenia. Neuropsychopharmacology 30: 1521-1531.

Scarr E, Pavey G, Sundram S, MacKinnon A, Dean B (2003). Decreased hippocampal NMDA, but not kainate or AMPA receptors in bipolar disorder. Bipolar Disord 5: 257-264.

Scoville WB, Milner B (1957). Loss of recent memory after bilateral hippocampal lesions. J Neurol Neurosurg Psychiatry 20: 11-21.

Selig DK, Hjelmstad GO, Herron C, Nicoll RA, Malenka RC (1995). Independent mechanisms for long-term depression of AMPA and NMDA responses. Neuron 15: 417-426.

Sheng M, Cummings J, Roldan LA, Jan YN, Jan LY (1994). Changing subunit composition of heteromeric NMDA receptors during development of rat cortex. Nature 368: 144-147.

Siegel BW, Sreekrishna K, Baron BM (1996). Binding of the radiolabeled glycine site antagonist $\left[{ }^{3} \mathrm{H}\right] \mathrm{MDL} 105,519$ to homomeric NMDA-NR1a receptors. Eur J Pharmacol 312: 357-365.

Siegel SJ, Janssen WG, Tullai JW, Rogers SW, Moran T, Heinemann SF et al (1995). Distribution of the excitatory amino acid receptor subunits GluR2(4) in monkey hippocampus and colocalization with subunits GluR5-7 and NMDAR1. J Neurosci 15: 2707-2719.

Sills MA, Fagg G, Pozza M, Angst C, Brundish DE, Hurt SD et al (1991). [ ${ }^{3} \mathrm{H}$ ]CGP 39653: a new $N$-methyl-D-aspartate antagonist radioligand with low nanomolar affinity in rat brain. Eur $J$ Pharmacol 192: 19-24.

Squire LR, Zola-Morgan S (1991). The medial temporal lobe memory system. Science 253: 1380-1386.

Stefanacci L, Suzuki WA, Amaral DG (1996). Organization of connections between the amygdaloid complex and the perirhinal and parahippocampal cortices in macaque monkeys. J Comp Neurol 375: 552-582.

Strack S, Colbran RJ (1998). Autophosphorylation-dependent targeting of calcium/calmodulin-dependent protein kinase II by the NR2B subunit of the $\mathrm{N}$-methyl-D-aspartate receptor. J Biol Chem 273: 20689-20692.

Strack S, McNeill RB, Colbran RJ (2000). Mechanism and regulation of calcium/calmodulin-dependent protein kinase II targeting to the NR2B subunit of the $N$-methyl-D-aspartate receptor. J Biol Chem 275: 23798-23806.

Sucher NJ, Akbarian S, Chi CL, Leclerc CL, Awobuluyi M, Deitcher $\mathrm{DL}$ et al (1995). Developmental and regional expression pattern of a novel NMDA receptor-like subunit (NMDAR-L) in the rodent brain. J Neurosci 15: 6509-6520.
Suzuki WA (1996). The anatomy, physiology and functions of the perirhinal cortex. Curr Opin Neurobiol 6: 179-186.

Suzuki Y, Jodo E, Takeuchi S, Niwa S, Kayama Y (2002). Acute administration of phencyclidine induces tonic activation of medial prefrontal cortex neurons in freely moving rats. Neuroscience 114: 769-779.

Takahata R, Moghaddam B (2003). Activation of glutamate neurotransmission in the prefrontal cortex sustains the motoric and dopaminergic effects of phencyclidine. Neuropsychopharmacology 28: 1117-1124.

Tamminga CA, Thaker GK, Buchanan R, Kirkpatrick B, Alphs LD, Chase TN et al (1992). Limbic system abnormalities identified in schizophrenia using positron emission tomography with fluorodeoxyglucose and neocortical alterations with deficit syndrome. Arch Gen Psychiatry 49: 522-530.

Torrey EF, Webster M, Knable M, Johnston N, Yolken RH (2000). The stanley foundation brain collection and neuropathology consortium. Schizophr Res 44: 151-155.

Ulas J, Nguyen L, Cotman C (1993). Chronic haloperidol treatment enhances binding to NMDA receptors in rat cortex. Neuroreport 4: 1049-1051.

Velakoulis D, Pantelis C, McGorry PD, Dudgeon P, Brewer W, Cook M et al (1999). Hippocampal volume in first-episode psychoses and chronic schizophrenia: a high-resolution magnetic resonance imaging study. Arch Gen Psychiatry 56: 133-141.

Wan H, Aggleton JP, Brown MW (1999). Different contributions of the hippocampus and perirhinal cortex to recognition memory. J Neurosci 19: 1142-1148.

Weinberger DR (1999). Cell biology of the hippocampal formation in schizophrenia. Biol Psychiatry 45: 395-402.

White BH, Vogel MW (1996). CGP 39653 binding in the chick CNS after NMDA receptor antagonist treatment. J Neural Transm 103: 1247-1253.

Wright IC, Rabe-Hesketh S, Woodruff PW, David AS, Murray RM, Bullmore ET (2000). Meta-analysis of regional brain volumes in schizophrenia. Am J Psychiatry 157: 16-25.

Wu G, Malinow R, Cline HT (1996). Maturation of a central glutamatergic synapse. Science 274: 972-976.

You L, Yin J (2000). Patterns of regulation from mRNA and protein time series. Metab Eng 2: 210-217.

Zhu JJ, Malinow R (2002). Acute versus chronic NMDA receptor blockade and synaptic AMPA receptor delivery. Nat Neurosci 5: 513-514.

Supplementary Information accompanies the paper on the Neuropsychopharmacology website (http://www.nature.com/npp) 